\title{
Determinants Of The Use Of Special Purpose Companies (SPCs) On Pre- And Post-IFRS: Empirical Evidence From Korea
}

Su-In Kim, Ewha Womans University, South Korea

Heejeong Shin, Ewha Womans University, South Korea

Hyejeong Shin, Ewha Womans University, South Korea

\begin{abstract}
We investigate which factors determine the use of a special purpose company (SPC) by a sponsoring company and whether those determinants differ before and after IFRS (International Financial Reporting Standards) adoption. Using financial data from Korean listed companies, our results indicate that use of an SPC is associated with financial reporting incentives (e.g., lowering leverage) and economic benefits (e.g., fundraising). However, the effect of leverage on the use of SPCs is not significant after the adoption of the IFRS. These results suggest that, although companies are generally motivated to use SPCs for both financial reporting and economic purposes, only economic motivation influences the use of SPCs after IFRS adoption. This implies that the regulation for reporting an SPC's consolidated financial statement under IFRS plays a role in decreasing the use of SPCs for financial reporting discretion. We extend the prior literature on SPCs by documenting the effects of IFRS adoption on the determinants of the use of SPCs.
\end{abstract}

Keywords: Special Purpose Company (SPC), Consolidated Financial Statement, Off-Balance Sheet Financing, Discretionary Financial Reporting

\section{INTRODUCTION}

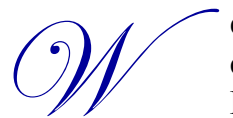

e investigate the factors that determine the use of a special purpose company (SPC) by a sponsoring company and whether those determinants differ before and after IFRS (International Financial Reporting Standards) adoption. The K-IFRS (Korean International Financial Reporting Standards) define an $\mathrm{SPC}^{1}$ as a legally distinct entity introduced to carry out a narrow, predefined activity for a sponsoring company. Previous literature on the use of SPCs documents that sponsoring companies use SPCs to more easily securitize financial assets (Thomas, 1999; Gorton \& Souleles, 2007). For example, a sponsoring company sells financial assets to an SPC, which purchases the financial assets through the issuance of new securities, mainly asset backed securities (ABS). Thus, SPCs are intended as instruments that can allow sponsoring companies to more easily acquire outside financing. That is, the use of an SPC can positively influence the sponsoring company's firm value by allowing it to raise capital at a lower borrowing cost and without reporting debt.

However, SPCs might also be used by sponsoring companies to disguise the sponsor's financial statements. Enron used SPCs to hide very large losses from its financial statements by taking advantage of legally separate entity status (Powers 2002).

It is important to investigate companies' incentives for using SPCs because the economic consequences could vary according to the sponsoring firm's motivation, economic benefits, or financial reporting discretion. First, sponsoring companies could use an SPC to improve their capital structure or obtain tax benefits. SPCs have economic benefits

${ }^{1}$ A special purpose company (SPC) is also called a special purpose vehicle or special purpose entity.

Copyright by author(s); $\underline{\mathrm{CC}-\mathrm{BY}}$ 
for sponsoring companies by serving the legitimate business purpose of raising capital at a lower borrowing $\operatorname{cost}^{2}$. Many studies document the wealth effects of SPCs (Rosenthal \& Ocampo, 1988; John \& John, 1991; Schwarcz, 1994; Lockwood, Rutherford \& Herrera, 1996), arguing that SPCs are useful for raising funds and thus contribute to optimal firm capital structure. In addition, SPCs are used frequently for tax purposes, mostly for optimal allocation of tax benefits among the investor classes (Korean Financial Supervisory Service, 2012).

On the other hand, using SPCs with financial reporting motivation, as Enron did, would harm investors by hiding information on firm value. Enron's collapse in the early 2000 is often presented as a typical example of such a misuse of SPCs.

K-IFRS regulations specify that SPCs should be consolidated into the sponsor's financial statement, which should remove the motivation to create SPCs for the purpose of financial statement discretion. Since adoption of the IFRS, sponsoring companies should use SPCs just for the purpose of economic benefits (i.e., raising capital and tax incentives). The Korean Financial Supervisory Service reports that the number of SPCs has not decreased since the IFRS was adopted in 2011, suggesting that sponsoring companies still use SPCs to raise funds and obtain tax benefits.

We develop a hypothesis about whether the use of SPCs is motivated by both financial reporting and economic benefits in the Korean market. We form a second hypothesis about the different motivations before and after IFRS adoption. More specifically, we conjecture that, since the adoption of the IFRS, the use of SPCs is not associated with financial reporting motivation and is driven by economic motivation.

Using a sample of Korean companies listed on the Korean Stock Exchanges (KSE) and KOSDAQ market from 2004 to 2014, we find evidence that sponsors use SPCs for both financial reporting and economic purposes. However, the relationship between the use of SPCs and financial reporting motivation is not significant after the adoption of IFRS. These results imply that financial reporting discretion through the use of SPCs is no longer available after the adoption of the IFRS because sponsoring companies must now consolidate SPCs into their financial statements.

We extend the literature in several ways. We document the determinants of the use of SPCs and also the effects of IFRS adoption in changing those determinants. In particular, our investigation of the role of regulation is differentiated from previous studies on the analysis under non-IFRS conditions. Our findings show the loss of motivation for financial reporting discretion after sponsoring companies applied the IFRS, which suggests that the IFRS regulation plays a crucial role in undermining the motivation for improper use of SPCs. Finally, this study adds to the literature on the consequences to the accounting environment of IFRS adoption.

The rest of paper is consisted as follows. Section II provides background and hypothesis development. Section III describes the sample and empirical model, and Section IV reports the results of the empirical tests. In Section V, we conclude and suggest future research.

\section{BACKGROUND AND HYPOTHESIS DEVELOPMENT}

\subsection{What is an SPC?}

K-IFRS defines an SPC as a legally separate entity created to perform designated transactions for a sponsoring company. SPCs have been used in the forms of a limited partnership, a limited liability company, or a trust for various financial arrangements. However, they have been used most frequently in asset securitization transactions (Hodge 1998).

Figure 1 shows a typical SPC formation for asset securitization. A sponsor creates an SPC to carry out transactions of circumscribed activities and sells assets to the SPC (Gorton \& Souleles, 2007). Then the SPC raises capital through the issuance of ABS. Using those funds, the SPC purchases assets from the sponsor, who guarantees the SPC's debt to the lender.

\footnotetext{
${ }^{2}$ The assets of an SPC are not legally associated with the sponsoring company's bankruptcy risk (Feng et al. 2009). 
Figure 1. Forming a Typical Special Purpose Company (SPC) $)^{3}$

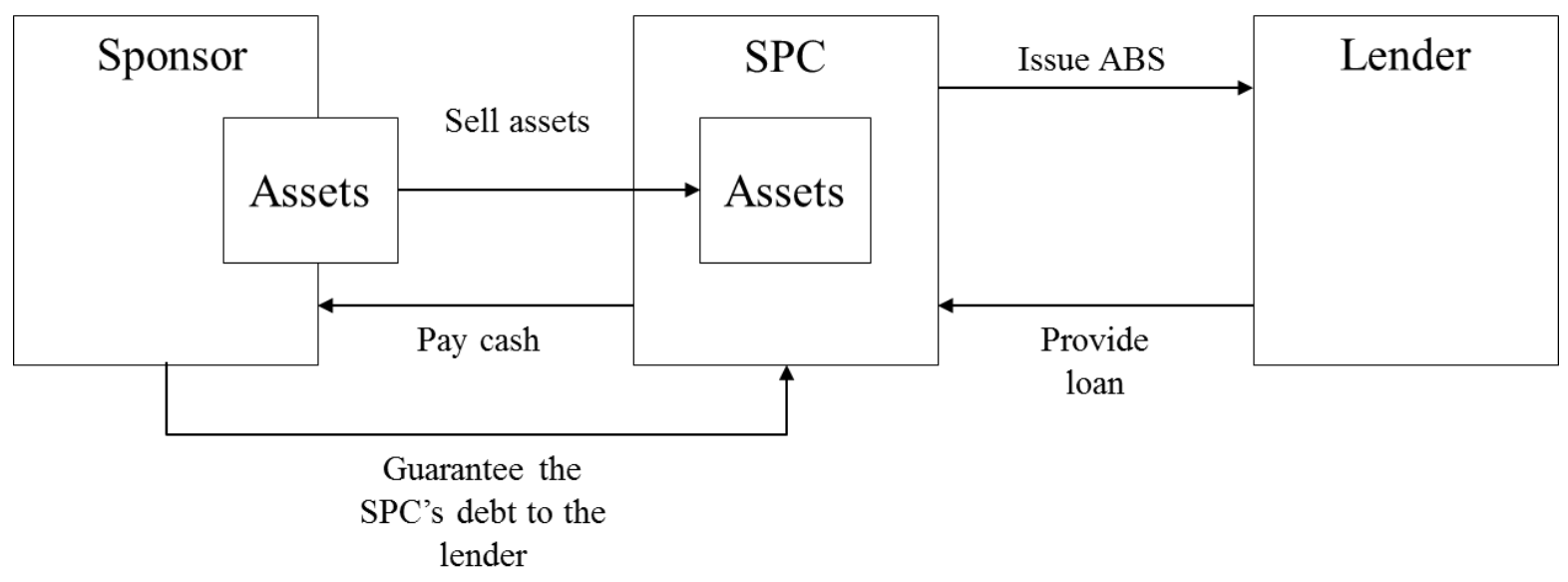

\subsection{Prior Studies and Hypotheses}

Previous studies have examined the effect of SPCs' financial statements and the usefulness of SPCs in raising funds. The literature focuses largely on the wealth effects of SPCs and how SPCs can contribute to optimal firm capital structure (Schwarcz, 1994; Rosenthal \& Ocampo, 1988; John \& John, 1991; Lockwood et al. 1996). Recent research emphasizes the extent of off-balance-sheet financing and the capital market reaction to SPCs (Shevlin, 1987; Beatty, Berger \& Magliolo, 1995; Calomiris \& Mason, 2004; Karaoglu, 2005; Mills \& Newberry, 2005; Feng, Gramlich \& Gupta, 2009; Dechow, Myers \& Shakespeare, 2010; Barth, Ormazabal \& Taylor, 2011). However, there is no consensus on the primary determinants for the use of an SPC in the Korean market. Thus, it remains an open question which factors mainly affect the use of SPCs in Korea. SPCs are usually created under the ABS (Asset-Backed Securitization) Act in Korea, which addresses SPCs' inherent risk. To protect investors, the ABS Act allows only sponsors with good credit to create SPCs.

To reduce the risk of an SPC, the sponsor guarantees the SPC's loans or agrees to incur underlying losses that result from the assets moved to the SPC (Calomiris \& Mason, 2004; Higgins \& Mason, 2004; Gorton \& Souleles, 2007). However, the SPC's assets and liabilities are not legally associated with the sponsor's bankruptcy risk. Therefore, the SPC allows the sponsor to raise funds at lower borrowing costs because the sponsoring company's substantial control of the SPC makes the SPC a low credit risk. Furthermore, SPCs are an easy way for sponsors to raise funds because the sponsors can choose assets that correspond to investors' risk preferences when they transfer assets to SPCs (Feng et al. 2009).

Sponsors frequently create SPCs as flow-through entities to share tax benefits with investors. In the United States, an SPC is used as a form of partnership to reduce income taxes because the SPC is subject to only a single level (shareholder level) of tax (Feng et al. 2009). Similarly, in Korea, SPCs are used to reduce income tax because they are not subject to the corporate level of tax. When SPCs distribute at least 90 percent of their distributable profits, that amount is deducted from the amount of income ${ }^{4}$ while corporations are subject to two levels of taxation (corporate and shareholder levels). Furthermore, prior studies show that companies extensively create flow-through entities for the purpose of tax planning (Fox \& Luna, 2005).

Collectively, sponsors are thus motivated to create SPCs for economic benefits such as raising capital at lower borrowing costs or allocating tax benefits.

\footnotetext{
${ }^{3}$ ABS practical guidance (Korean Financial Supervisory Service. 2012. 8)

${ }^{4}$ Korean corporate tax act article 51-2.
}

Copyright by author(s); $\underline{\mathrm{CC}-\mathrm{BY}}$ 
We also expect that sponsors are motivated to create SPCs for financial reporting discretion. The sponsor manages its financial statements in terms of timing and amount of debt. Because the sponsor defines the SPC's activities and contract details in advance, it can control the SPC's transactions and obtain the best balance of risks and rewards (Weidner, 1999; Berardino, 2001; Soroosh \& Ciesielski, 2004).

Based on the above discussion, we predict that SPCs are used for both financial reporting motivation and economic motivation and we develop the hypothesis as follows.

H1: The use of SPCs is motivated by both financial reporting discretion and economic benefits.

A sponsor can use an SPC for financial reporting discretion when the SPC's financial statements are excluded from consolidation with the sponsor's financial statements. As presented in Table 1, however, K-IFRS does not exclude SPCs from consolidation into their sponsors' financial statements. Accordingly, sponsoring companies must report consolidated financial statements that include their SPCs, which implies that the use of SPCs for financial reporting discretion is ineffective since the adoption of the IFRS.

Table 1. Consolidation scope before and after adoption of IFRS

\begin{tabular}{l|l|l}
\hline Consolidation scope & $\begin{array}{l}\text { A company which has the total assets at the end of } \\
\text { the immediately preceding business year falls } \\
\text { short of the amount of tem billion won or less shall } \\
\text { be deemed not to be included in the scope of } \\
\text { subsidiary companies and so on. }\end{array}$ & \multicolumn{1}{c}{ K-IFRS } \\
\hline Exception for SPC & $\begin{array}{l}\text { SPC shall not to be included in the scope of } \\
\text { subsidiary companies. }\end{array}$ & No exception \\
\hline
\end{tabular}

Even though accounting regulations have changed, the Korean Financial Supervisory Service reports that the number of SPCs has not decreased since IFRS adoption. This implies that sponsoring companies still employ SPCs for their economic benefits of raising funds and obtaining tax benefits.

This suggests that IFRS adoption might influence the determinants for the use of SPCs, thus, we conjecture that the determinants for using SPCs differ before and after IFRS adoption. Specifically, the sponsor's motivation to use SPCs for financial reporting discretion would be attenuated during the post-IFRS period. Therefore, we develop the second hypothesis as follows.

H2: The use of SPCs has not been motivated by financial reporting discretion since the adoption of the IFRS.

\section{METHODOLOGY}

\subsection{Sample Selection}

Our sample consists of 15,068 firm-year observations listed on the KSE or KOSDAQ from 2004 to 2014. We exclude companies in the financial industry due to inherent differences in their regulatory and institutional structures. Also, we use sponsoring companies with SPCs established under the ABS Act due to limitations in data collection ${ }^{6}$.

Table 2 represents a distribution of our sample by year and by industry. Panel A shows the frequency and extent of the using SPC during the sample period. The number of sponsoring companies belonging to industries with SPCs is

\footnotetext{
${ }^{5}$ Until 2003, the U.S. GAAP allowed an SPC's financial statements to be excluded from consolidation into the sponsor's financial statements when the third-party residual equity investment was equal to at least 3 percent of the SPC's total capitalization. K-GAAP also permitted the exclusion of SPCs from the sponsor firm's financial statements.

${ }^{6}$ In Korea, sponsors can create SPCs under commercial law and the Asset-Backed Securitization Act (ABS Act). Some terms to protect investors, such as income deductions and limitations of originator (financial institutions, public enterprise, and corporations of good credit) apply to SPCs intended to facilitate asset securitization under the ABS Act.
}

Copyright by author(s); $\underline{\mathrm{CC}-\mathrm{BY}}$ 
8,217 firm-years, approximately $55 \%$ of the total observations. The number of companies with SPCs is 53, which is $0.35 \%$ of the full observations and $0.65 \%$ of the observations in industries with at least one SPC. After IFRS adoption in 2011, the mean value of companies with at least one SPC decreases from 5.29 to $4^{7}$, while the mean and median of SPCs per sponsoring company increase ${ }^{8}$.

Panel B shows the distribution of our sample across the industry categories. The use of SPCs is frequent among the industry groups of air transport, telecommunications, and construction. Since the adoption of the IFRS, only companies in the industry groups of air transport, water transport, telecommunications, and manufacturing of nonmetallic mineral products have used SPCs. Compared with the pre-IFRS adoption period, the mean value increases from $1.30^{9}$ to 3.38 , indicating that SPC use is concentrated in certain industries.

In summary, since the adoption of the IFRS, companies in certain industry groups use SPCs, although the number of companies with SPC decreased ${ }^{10}$.

Table 2. Sample Distribution

\begin{tabular}{|c|c|c|c|c|c|c|c|}
\hline \multicolumn{8}{|c|}{ Panel A: Sample Distribution by Year } \\
\hline \multirow[t]{2}{*}{ Year } & \multirow{2}{*}{$\begin{array}{c}\text { No. of } \\
\text { Observations } \\
\text { (1) }\end{array}$} & \multirow{2}{*}{$\begin{array}{c}\text { No. of Observations } \\
\text { of Companies in } \\
\text { industries with SPC } \\
\text { (2) }\end{array}$} & \multirow{2}{*}{$\begin{array}{c}\begin{array}{c}\text { No. of } \\
\text { Companies } \\
\text { with SPC }\end{array} \\
(3)\end{array}$} & \multicolumn{2}{|c|}{$\begin{array}{c}\text { Percent of Companies } \\
\text { with SPC }\end{array}$} & \multicolumn{2}{|c|}{$\begin{array}{c}\text { No. of SPCs per } \\
\text { sponsoring company }\end{array}$} \\
\hline & & & & (3)/(1) & $(3) /(2)$ & Mean & Median \\
\hline 2004 & 1,174 & 642 & 7 & $0.60 \%$ & $1.09 \%$ & 1.71 & 1.00 \\
\hline 2005 & 1,244 & 682 & 5 & $0.40 \%$ & $0.73 \%$ & 1.20 & 1.00 \\
\hline 2006 & 1,297 & 702 & 5 & $0.39 \%$ & $0.71 \%$ & 1.00 & 1.00 \\
\hline 2007 & 1,352 & 732 & 6 & $0.44 \%$ & $0.82 \%$ & 1.00 & 1.00 \\
\hline 2008 & 1,364 & 738 & 2 & $0.15 \%$ & $0.27 \%$ & 1.00 & 1.00 \\
\hline 2009 & 1,389 & 768 & 6 & $0.43 \%$ & $0.78 \%$ & 1.50 & 1.00 \\
\hline 2010 & 1,387 & 764 & 6 & $0.43 \%$ & $0.79 \%$ & 1.33 & 1.00 \\
\hline 2011 & 1,400 & 763 & 2 & $0.14 \%$ & $0.26 \%$ & 2.00 & 2.00 \\
\hline 2012 & 1,453 & 795 & 5 & $0.34 \%$ & $0.63 \%$ & 2.60 & 1.00 \\
\hline 2013 & 1,501 & 811 & 5 & $0.33 \%$ & $0.62 \%$ & 3.40 & 2.00 \\
\hline \multirow[t]{2}{*}{2014} & 1,507 & 820 & 4 & $0.27 \%$ & $0.49 \%$ & 5.00 & 6.00 \\
\hline & 15,068 & 8,217 & 53 & $0.35 \%$ & $0.65 \%$ & 1.92 & 1.00 \\
\hline
\end{tabular}

(Table 2 continued on next page)

\footnotetext{
${ }^{7}$ The mean of companies with at least one SPC between 2004 and 2010 is 5.29, and the mean of companies with at least one SPC between 2011 and 2014 is 4.

${ }^{8}$ The mean (median) of SPCs per sponsoring company is 1.25 (1.00) between 2004 and 2010 and 3.25 (2.75) between 2011 and 2014.

${ }^{9}$ The mean of SPCs among firm-years with SCPs presented in Table 2 is defined as the total number of SPCs divided by the number of observations with at least one SPC before and after the adoption of IFRS. The total numbers of SPCs before adoption, after adoption, and in the whole sample period are 48,54 , and 102 , respectively.

${ }^{10}$ For instance, the number of companies with SPCs in the telecommunications industry increases from 4 to 7 after adoption of the IFRS. The Korean Financial Supervisory Service reports that asset securitizations of receivables for phone devices increase through increased demand for smartphones.
}

Copyright by author(s); $\underline{\mathrm{CC}-\mathrm{BY}}$ 
(Table 2 continued)

\begin{tabular}{|c|c|c|c|c|c|c|}
\hline \multicolumn{7}{|c|}{ Panel B: Sample Distribution by Industry Categories by IFRS adoption } \\
\hline \multirow[b]{2}{*}{ Industry Categories } & \multicolumn{2}{|c|}{ All } & \multicolumn{2}{|c|}{ Pre_IFRS } & \multicolumn{2}{|c|}{ Post_IFRS } \\
\hline & $\begin{array}{c}\text { No. of } \\
\text { Observations }\end{array}$ & $\begin{array}{c}\text { No. of } \\
\text { Observations } \\
\text { with SPC }\end{array}$ & $\begin{array}{c}\text { No. of } \\
\text { Observations } \\
\text { with SPC }\end{array}$ & $\begin{array}{l}\text { Mean of } \\
\text { SPCs per } \\
\text { sponsoring } \\
\text { company }\end{array}$ & $\begin{array}{c}\text { No. of } \\
\text { Observations } \\
\text { with SPC }\end{array}$ & $\begin{array}{c}\text { Mean of } \\
\text { SPCs per } \\
\text { sponsoring } \\
\text { company }\end{array}$ \\
\hline Air Transport & 22 & 12 & 6 & 2.00 & 6 & 2.67 \\
\hline Telecommunications & 125 & 11 & 4 & 1.50 & 7 & 5.00 \\
\hline Construction & 491 & 5 & 5 & 1.40 & & \\
\hline Water Transport & 49 & 5 & 3 & 1.33 & 2 & 1.00 \\
\hline $\begin{array}{l}\text { Manufacture of } \\
\text { Pharmaceuticals, } \\
\text { Medicinal Chemicals } \\
\text { and Botanical Products }\end{array}$ & 829 & 4 & 4 & 1.00 & & \\
\hline $\begin{array}{l}\text { Manufacture of } \\
\text { Electronic Components, } \\
\text { Computer, Radio, } \\
\text { Television and } \\
\text { Communication } \\
\text { Equipment and } \\
\text { Apparatuses }\end{array}$ & 2150 & 3 & 3 & 1.00 & & \\
\hline $\begin{array}{l}\text { Manufacture of } \\
\text { chemicals and chemical } \\
\text { products except } \\
\text { pharmaceuticals, } \\
\text { medicinal chemicals }\end{array}$ & 942 & 2 & 2 & 1.00 & & \\
\hline $\begin{array}{l}\text { Manufacture of Basic } \\
\text { Metal Products }\end{array}$ & 780 & 2 & 2 & 1.00 & & \\
\hline $\begin{array}{l}\text { Manufacture of } \\
\text { electrical equipment }\end{array}$ & 523 & 2 & 2 & 1.00 & & \\
\hline Professional Services & 675 & 2 & 2 & 1.00 & & \\
\hline $\begin{array}{l}\text { Manufacture of Food } \\
\text { Products }\end{array}$ & 451 & 1 & 1 & 1.00 & & \\
\hline $\begin{array}{l}\text { Manufacture of wearing } \\
\text { apparel, Clothing } \\
\text { Accessories and Fur } \\
\text { Articles }\end{array}$ & 222 & 1 & 1 & 1.00 & & \\
\hline $\begin{array}{l}\text { Manufacture of Rubber } \\
\text { and Plastic Products }\end{array}$ & 369 & 1 & 1 & 1.00 & & \\
\hline $\begin{array}{l}\text { Manufacture of Other } \\
\text { Non-metallic Mineral } \\
\text { Products }\end{array}$ & 325 & 1 & & & 1 & 1.00 \\
\hline \multirow[t]{2}{*}{$\begin{array}{l}\text { Manufacture of } \\
\text { Medical, Precision and } \\
\text { Optical Instruments, } \\
\text { Watches and Clocks }\end{array}$} & 264 & 1 & 1 & 1.00 & & \\
\hline & 8,217 & 53 & 37 & 1.30 & 16 & 3.38 \\
\hline
\end{tabular}

\subsection{Model Specification}

For the test model to investigate the determinants of the use of SPCs, we refer to Feng et al. (2009). They estimate a Tobit model with financial reporting variables, economic variables, and control variables.

We use the number of SPCs (SPC_NUM) and a dummy variable for SPCs (SPC_DUM) as dependent variables. We estimate the Tobit specification because SPC_NUM is greater than zero, which means the dependent variable is left- 
censored (Wooldridge, 2010; Greene, 2003). Also, we estimate the logit model when we use SPC_DUM as another proxy for the use of SPCs.

Our model is specified as follows.

$$
\begin{aligned}
& S P C_{i, t}=\alpha+\beta_{1} L_{E V} V_{i, t-1}+\beta_{2} \text { INCOV }_{i, t-1}+\beta_{3} \text { DEBTISS }_{i, t+1}+\beta_{4} \text { STOCKISS }_{i, t+1}+\beta_{5} \text { RISK }_{i, t-1} \\
& +\beta_{6} \text { FUND }_{i, t-1}+\beta_{7} \text { ETR R }_{i, t-1}+\beta_{8} \text { INTAN }_{i, t-1}+\beta_{9} \text { DIRIND }_{i, t-1}+\beta_{10} \text { INDSH }_{i, t-1}++\beta_{11} \text { LnSIZE }_{i, t-1} \\
& +\beta_{12} I N D U_{-} P E R C_{i, t-1}+\beta_{j} \sum_{13}^{22} Y E A R_{-} D U M_{i, t}+\epsilon_{i, t}
\end{aligned}
$$

We include the leverage ratio (LEV) and the ratio of operating income to interest expense (INTCOV) as proxies for the closeness to debt covenant violations as the financial reporting motivation. We also use variables of financing from outside investors (DEBTISS and STOCKISS) as financial reporting variables. We use firm-specific risk (RISK), accessibility of internal funds (FUND), repayable funds (CLTD), and tax incentives (ETR and INTAN) as proxies for economic motivation. The control variables are board characteristics (DIRIND, INDSH), firm size (LnSIZE), and industry practice (INDU PERC). We include year dummies (YEAR) to capture year effects.

For the independent variables, we use one year preceding data to minimize endogeneity concerns. However, for the variables of financing from outside investors (DEBTISS and STOCKISS), we measure at $t+1$ as a proxy for management incentive to manage financial statements discretionally before raising funds from outside investors.

\begin{tabular}{|c|c|c|c|}
\hline & Variable & Definition & $\begin{array}{l}\text { Predicted } \\
\text { sign }\end{array}$ \\
\hline \multirow{2}{*}{$\begin{array}{l}\text { Dependent } \\
\text { Variables }\end{array}$} & SPC_NUM & The number of SPC & \\
\hline & SPC D DUM & Company with SPCs is 1 , otherwise 0 & \\
\hline \multirow{4}{*}{$\begin{array}{l}\text { Independent } \\
\text { Variables: } \\
\text { Financial Reporting } \\
\text { Motivations }\end{array}$} & LEV & Total debt/ total assets & + \\
\hline & INTCOV & Operating income/interest expense & - \\
\hline & DEBTISS & $\Delta$ long-term debt / average total assets & + \\
\hline & STOCKISS & $\Delta$ common and preferred stock / average total assets & + \\
\hline \multirow{5}{*}{$\begin{array}{l}\text { Independent } \\
\text { Variables: } \\
\text { Economic } \\
\text { Motivations }\end{array}$} & RISK & The decile of the standard deviation of daily stock returns for the year & $?$ \\
\hline & FUND & Cash flow from operating and investing activities/ average total assets & - \\
\hline & CLTD & Debt in current liabilities / total assets & + \\
\hline & ETR & Income tax expense / total pretax income & + \\
\hline & INTAN & Intangible assets / total assets & + \\
\hline \multirow{4}{*}{ Control Variables } & DIRIND & The percentage of independent directors in the Board & $?$ \\
\hline & INDSH & Independent directors' shareholding ratio & $?$ \\
\hline & LnSIZE & $\begin{array}{l}\ln \text { (market value of common shares and preferred stock and the book } \\
\text { value of liabilities) }\end{array}$ & + \\
\hline & INDU_PERC & Percent of companies with SPCs for each industry-year & + \\
\hline
\end{tabular}

Table 3 summarizes the definitions of the variables used in our model.

Table 3. Variable Definitions

Companies have to meet minimum financial requirements to avoid violation of lending arrangements. We use LEV, as a proxy for the closeness to a debt covenant violation, which is calculated as total debt divided by total assets and INTCOV, which is calculated as the ratio of operating income to interest expense (Press \& Weintrop, 1990; Duke \& Hunt 1990; Dichev \& Skinner 2002), as a second financial reporting variable. We expect the use of SPCs to increase with LEV and decrease with INTCOV.

Companies also have motivation to perform earnings management to attract external financing (Dechow, Sloan \& Sweeney, 1996). Consistent with this notion, companies usually engage in earnings management before capital issuances (Teoh, Welch \& Wong, 1998). Therefore, we use DEBTISS, defined as the increase in debt in year $\mathrm{t}+1$, and STOCKISS, the net stock issuances in year $\mathrm{t}+1$, both divided by average total assets, as financial reporting variables to represent companies' incentives to manage their financial statements in the previous year of financing from outside investors. We expect both variables to be positive. 
Sponsors transfer an asset or group of assets with similar risks to SPCs to meet the demands of investors with specific risk preferences. Sponsors might sell more (fewer) risky assets to SPCs when they are seeking finance from risktaking (averse) investors (Beatty et al. 1995). Hence, we do not predict the sign of the coefficient for RISK, defined as the decile of standard deviations of all companies' daily stock returns, as an economic variable to capture management incentive to remove risky assets and liabilities to SPCs.

Also, we use the variables of internal fund availability (FUND) and repayable funds (CLTD) (Beatty et al., 1995) because companies will use SPCs when internal funding is tight. FUND is calculated as the sum of cash flow from operating activity and investing activity deflated by average total assets. CLTD is defined as the ratio of long-term debt due within one year to total assets. We predict that using SPCs will decrease with FUND and increase with CLTD.

Companies engage in tax planning using flow-through entities to share tax benefits with investors (Fox \& Luna 2005). Flow-through entities are subject to only a shareholder level of tax, whereas corporations are subject to both corporate and shareholder levels of tax (Feng et al. 2009). In Korea, when companies distribute at least 90 percent of the distributable profits of SPCs, that amount is deducted from the amount of income (Korean corporate tax act article 512). Therefore, we use ETR, defined as the sum of income tax expenses divided by pretax income, as the proxy for tax incentives. Also, companies shift income generated from intangibles into low-tax regions (Dischinger \& Riedel 2011). Thus, we include INTAN, defined as the ratio of intangible assets to total assets, as a proxy for tax incentives. We predict the use of SPCs to increase with ETR and INTAN.

We include board characteristics as control variables. We use DIRIND, calculated as the ratio of independent directors in the board, and INDSH, independent directors' shareholding ratio, as a proxy of the independence of board members associated with earnings management (Larcker, Richardson \& Tuna, 2007). Prior research shows that, as a board's number of independent directors increases, its monitoring becomes more effective, it better aligns the interests of shareholders and managers (Byrd \& Hickman 1992; Brickley, Coles \& Terry, 1994), and shareholder value increases (Klein 1998).

We also control for firm size (LnSIZE), industry practice (INDU_PERC), and year. We use LnSIZE, which is calculated as the natural log of the market value of equity and the book value of debt, as a control variable. Because larger companies are more likely to have experts to deal with complicated finance arrangements, we expect the use of SPCs to increase with LnSIZE. INDU_PERC captures industry practice, calculated as the ratio of companies with at least one SPC by industry and year. To the extent that using SPCs is likely to be affected by industry practices, we predict the use of SPCs to increase with INDU_PERC. Finally, to capture other systematic economy-wide effects, we include year dummies (YEAR).

\section{EMPIRICAL ANALYSIS RESULTS}

\subsection{Descriptive Statistics}

Table 4 contains the descriptive statistics for the variables. The mean value of SPC_NUM after the adoption of the IFRS is higher than that before IFRS adoption, whereas the mean value of SPC_DUM is lower after IFRS adoption than it was before. Thus, although the number of companies using SPCs decreases after IFRS adoption, those companies use more SPCs than they did in the pre-IFRS adoption period. The mean (median) of LEV indicates no prominent difference before and after IFRS adoption. The means (medians) of INTCOV, DEBTISS, and STOCKISS after IFRS adoption are lower than those before IFRS adoption. However, the means (medians) of DIRIND and INDSH after IFRS adoption are higher than those before IFRS adoption.

The univariate test results for these variables pre- and post-IFRS adoption are reported in Table 5. Compared to companies without SPCs, companies reporting at least one SPC show higher LEV and lower INTCOV. In addition, companies with SPCs have lower RISK, a greater proportion of CLTD, higher ETR, and greater INTAN than companies without SPCs. 
Table 4. Descriptive Statistics

\begin{tabular}{|c|c|c|c|c|c|c|c|c|c|}
\hline & \multicolumn{5}{|c|}{ All $(N=15,068)$} & \multicolumn{2}{|c|}{ Pre_IFRS(N=9,207) } & \multicolumn{2}{|c|}{ Post_IFRS(N=5,861) } \\
\hline & Mean & Median & Max & Min & SD & Mean & Median & Mean & Median \\
\hline SPC_NUM & 0.007 & 0.000 & 7.000 & 0.000 & 0.152 & 0.005 & 0.000 & 0.009 & 0.000 \\
\hline SPC_DUM & 0.004 & 0.000 & 1.000 & 0.059 & 0.004 & 0.004 & 0.000 & 0.003 & 0.000 \\
\hline LEV & 0.474 & 0.473 & 1.534 & 0.033 & 0.214 & 0.475 & 0.471 & 0.471 & 0.475 \\
\hline INTCOV & 119.644 & 2.389 & 6399.857 & -187.202 & 714.806 & 127.429 & 2.073 & 107.417 & 2.934 \\
\hline DEBTISS & 0.013 & 0.000 & 1.043 & -1.056 & 0.259 & 0.018 & 0.000 & 0.004 & 0.000 \\
\hline STOCKISS & 0.043 & 0.000 & 0.889 & -0.052 & 0.139 & 0.056 & 0.000 & 0.023 & 0.000 \\
\hline RISK & 5.648 & 6.000 & 10.000 & 1.000 & 2.738 & 5.530 & 6.000 & 5.834 & 6.000 \\
\hline FUND & -0.044 & -0.012 & 0.336 & -0.893 & 0.166 & -0.058 & -0.013 & -0.023 & -0.010 \\
\hline CLTD & 0.032 & 0.008 & 0.324 & 0.000 & 0.053 & 0.032 & 0.008 & 0.032 & 0.008 \\
\hline STER & 0.133 & 0.178 & 1.288 & -1.655 & 0.341 & 0.130 & 0.174 & 0.137 & 0.181 \\
\hline INTAN & 0.037 & 0.012 & 0.375 & -0.011 & 0.065 & 0.033 & 0.007 & 0.044 & 0.018 \\
\hline DIRIND & 0.126 & 0.125 & 0.429 & 0.000 & 0.111 & 0.112 & 0.105 & 0.147 & 0.143 \\
\hline INDSH & 0.157 & 0.113 & 0.569 & 0.000 & 0.165 & 0.147 & 0.080 & 0.172 & 0.148 \\
\hline LnSIZE & 25.607 & 25.317 & 30.705 & 22.886 & 1.481 & 25.405 & 25.108 & 25.925 & 25.635 \\
\hline INDU PERC & 0.003 & 0.001 & 0.063 & 0.000 & 0.008 & 0.003 & 0.001 & 0.003 & 0.001 \\
\hline
\end{tabular}

Please refer to Table 3 for variable definitions.

Table 5. Univariate Tests of Explanatory Variables by Use of SPC

\begin{tabular}{|c|c|c|c|c|c|c|c|}
\hline & \multicolumn{2}{|c|}{ Companies without SPCs } & \multicolumn{2}{|c|}{ Companies with SPCs } & \multirow{3}{*}{$\begin{array}{c}\text { Pred. } \\
\text { Sign }\end{array}$} & \multirow{2}{*}{$\begin{array}{l}\text { Diff. Test } \\
\text { (T-Test) }\end{array}$} & \multirow{2}{*}{$\begin{array}{c}\text { Diff. Test } \\
\text { (Wilcoxon } \\
\text { Rank Sum } \\
\text { Test) }\end{array}$} \\
\hline & Mean & Median & Mean & Median & & & \\
\hline & (1) & (2) & (3) & (4) & & (3)-(1) & (4)-(2) \\
\hline LEV & 0.473 & 0.472 & 0.718 & 0.715 & + & $8.347^{* * *}$ & $8.564^{* * *}$ \\
\hline INTCOV & 120.062 & 2.411 & 1.466 & 0.860 & - & -1.206 & $-2.737^{* * *}$ \\
\hline DEBTISS & 0.013 & 0.000 & -0.004 & 0.025 & + & -0.456 & 0.643 \\
\hline STOCKISS & 0.043 & 0.000 & 0.004 & 0.000 & + & $-2.069^{* *}$ & -0.411 \\
\hline RISK & 5.656 & 6.000 & 3.415 & 3.000 & $?$ & $-5.955^{* * *}$ & $-5.960^{* * *}$ \\
\hline FUND & -0.044 & -0.012 & -0.009 & -0.010 & - & 1.564 & 1.126 \\
\hline CLTD & 0.032 & 0.008 & 0.115 & 0.107 & + & $11.449^{* * *}$ & $9.977^{* * *}$ \\
\hline STER & 0.133 & 0.178 & 0.205 & 0.228 & + & 1.537 & $2.511^{* *}$ \\
\hline INTAN & 0.037 & 0.012 & 0.043 & 0.025 & + & 0.587 & $2.464^{* *}$ \\
\hline DIRIND & 0.126 & 0.125 & 0.132 & 0.089 & $?$ & 0.433 & -0.061 \\
\hline INDSH & 0.157 & 0.114 & 0.044 & 0.006 & $?$ & $-5.000^{* * *}$ & $-3.664^{* * *}$ \\
\hline LnSIZE & 25.595 & 25.313 & 29.001 & 29.361 & + & $16.870^{* * *}$ & $11.021^{* * *}$ \\
\hline INDU_PERC & 0.003 & 0.001 & 0.023 & 0.005 & + & $18.349^{* * *}$ & $8.441^{* * *}$ \\
\hline $\mathrm{N}$ & 15,015 & & 53 & & & & \\
\hline
\end{tabular}

Please refer to Table 3 for variable definitions. 
Table 6. Univariate Tests of Explanatory Variables by Use of SPCs: Pre_IFRS vs. Post IFRS

\begin{tabular}{|c|c|c|c|c|c|c|c|}
\hline \multicolumn{8}{|c|}{ Panel A: Univariate Tests for Pre_IFRS } \\
\hline & Compan & thout SPCs & Compa & vith SPCs & \multirow{3}{*}{$\begin{array}{c}\text { Pred. } \\
\text { Diff. }\end{array}$} & Diff. Test & \multirow{2}{*}{$\begin{array}{c}\text { Diff. Test } \\
\text { (Wilcoxon Rank } \\
\text { Sum Test) }\end{array}$} \\
\hline & Mean & Median & Mean & Median & & (T-Test) & \\
\hline & (1) & (2) & (3) & (4) & & (3)-(1) & (4)-(2) \\
\hline LEV & 0.475 & 0.470 & 0.702 & 0.704 & + & $6.300^{* * *}$ & $6.740^{* * *}$ \\
\hline INTCOV & 127.935 & 2.084 & 1.904 & 1.207 & - & -1.015 & $-1.630^{* * *}$ \\
\hline DEBTISS & 0.018 & 0.000 & 0.021 & 0.025 & + & 0.055 & 0.497 \\
\hline STOCKISS & 0.056 & 0.000 & 0.004 & 0.000 & + & $-1.927^{*}$ & -0.604 \\
\hline RISK & 5.538 & 6.000 & 3.378 & 3.000 & $?$ & $-4.737^{* * *}$ & $-4.757^{* * *}$ \\
\hline FUND & -0.058 & -0.013 & -0.010 & -0.003 & - & 1.522 & 1.107 \\
\hline CLTD & 0.032 & 0.008 & 0.103 & 0.104 & + & $8.179^{* * *}$ & $7.982^{* * *}$ \\
\hline STER & 0.130 & 0.174 & 0.255 & 0.246 & + & $2.251^{* *}$ & $2.938^{* * *}$ \\
\hline INTAN & 0.033 & 0.007 & 0.036 & 0.018 & + & 0.285 & $1.937^{*}$ \\
\hline DIRIND & 0.112 & 0.105 & 0.147 & 0.100 & $?$ & $1.904^{*}$ & $1.728^{*}$ \\
\hline INDSH & 0.147 & 0.080 & 0.052 & 0.019 & $?$ & $-3.513^{* * *}$ & $-1.977^{* *}$ \\
\hline LnSIZE & 25.392 & 25.104 & 28.559 & 28.590 & + & $13.232^{* * *}$ & $9.063^{* * *}$ \\
\hline INDU_PERC & 0.003 & 0.001 & 0.018 & 0.002 & + & $11.647^{* * *}$ & $5.567^{* * *}$ \\
\hline $\mathrm{N}$ & 9,170 & & 37 & & & & \\
\hline
\end{tabular}

Panel B: Univariate Tests for Post_IFRS

\begin{tabular}{|c|c|c|c|c|c|c|c|}
\hline & \multicolumn{2}{|c|}{ Companies without SPCs } & \multicolumn{2}{|c|}{ Companies with SPCs } & \multirow{3}{*}{$\begin{array}{c}\text { Pred. } \\
\text { Diff. }\end{array}$} & Diff. Test & \multirow{3}{*}{\begin{tabular}{|c|} 
Diff. Test \\
$\begin{array}{c}\text { (Wilcoxon Rank } \\
\text { Sum Test) }\end{array}$ \\
$(4)-(2)$
\end{tabular}} \\
\hline & Mean & Median & Mean & Median & & (T-Test) & \\
\hline & (1) & (2) & (3) & (4) & & (3)-(1) & \\
\hline LEV & 0.470 & 0.474 & 0.757 & 0.827 & + & $5.574^{* * *}$ & $5.288^{* * * *}$ \\
\hline INTCOV & 107.709 & 2.938 & 0.452 & 0.262 & - & -0.661 & $-2.337^{* *}$ \\
\hline DEBTISS & 0.004 & 0.000 & -0.060 & 0.033 & + & -1.078 & 0.384 \\
\hline STOCKISS & 0.023 & 0.000 & 0.003 & 0.000 & + & -0.978 & 0.116 \\
\hline RISK & 5.840 & 6.000 & 3.500 & 3.000 & $?$ & $-3.499^{* * *}$ & $-3.417^{* * *}$ \\
\hline FUND & -0.023 & -0.010 & -0.004 & -0.010 & - & 0.632 & 0.478 \\
\hline CLTD & 0.032 & 0.008 & 0.145 & 0.130 & + & $8.409^{* * *}$ & $6.050^{* * *}$ \\
\hline STER & 0.137 & 0.181 & 0.087 & 0.191 & + & -0.580 & 0.129 \\
\hline INTAN & 0.044 & 0.018 & 0.057 & 0.048 & + & 0.818 & $2.502^{* *}$ \\
\hline DIRIND & 0.147 & 0.143 & 0.099 & 0.080 & $?$ & $-1.813^{*}$ & $-2.572^{* *}$ \\
\hline INDSH & 0.173 & 0.148 & 0.025 & 0.000 & $?$ & $-3.604^{* * *}$ & $-3.378^{* * *}$ \\
\hline LnSIZE & 25.914 & 25.630 & 30.021 & 30.016 & + & $11.469^{* * *}$ & $6.606^{* * *}$ \\
\hline INDU_PERC & 0.003 & 0.001 & 0.034 & 0.034 & + & $15.710^{* * *}$ & $6.972^{* * *}$ \\
\hline $\mathrm{N}$ & 5,845 & & 16 & & & & \\
\hline
\end{tabular}

Please refer to Table 3 for variable definitions.

These differences support our hypothesis that companies create SPCs for both financial reporting and economic purposes. The lower RISK of companies with SPCs stems from the condition of company credit that allows corporations to create SPCs (Korean ABS Act). Also, companies with at least one SPC show higher LnSIZE and INDU_PERC than companies without SPCs, indicating that SPC use is associated with company size and industry characteristics.

Table 6 reports univariate test results for the independent and control variables by the use of SPCs and the adoption of the IFRS. Similar to Table 5, Table 6 shows that companies arrange SPCs for both financial reporting and economic purposes before and after adoption of the IFRS. 


\subsection{Regression Analysis Results}

In this section, we run Tobit and logit models to investigate the determinants of using SPCs. Table 7 shows the analysis results. The coefficient on LEV is significantly positive for both SPC_NUM and SPC_DUM, whereas the coefficient on INTCOV is marginally negative only for SPC_NUM. We interpret this result to indicate that companies with greater leverage are more likely to use SPCs to avoid violation of debt covenants. However, we do not find that companies have incentives to manage financial statements before they acquire outside financing because the coefficients for DEBTISS and STOCKISS are not significant in either analysis.

In terms of economic motivation variables, we find a significantly negative coefficient on RISK and a significantly positive coefficient on CLTD, indicating that use of SPCs is more prevalent among companies with low risk and high demand to repay funds.

For the control variables, LnSIZE and INDU_PERC are positive and significant. These results show that larger companies are more likely to use SPCs, and that companies are affected in their use of SPCs by industry practices.

For RISK, INTAN, DIRIND, and INDSH, our results differ from those of Feng et al. (2009). The coefficient of RISK is significantly negative in our study, but not in Feng et al. (2009), because we use SPCs established under the ABS Act, which permits only companies with good credit to create SPCs. Also, we do not find significant relationships between the use of SPCs and INTAN, DIRIND, or INDSH. These results might be due to differences between Korean and US companies in tax planning and the role of boards of directors.

In summary, our regression results overall support hypothesis 1 that the use of SPCs is motivated by financial reporting and economic considerations.

Table 7. Analysis Results for Determinants of the Use of SPC

\begin{tabular}{|c|c|c|c|c|}
\hline \multirow{2}{*}{ Variables } & \multicolumn{2}{|c|}{ Dependent Variable=SPC_NUM } & \multicolumn{2}{|c|}{ Dependent Variable $=$ SPC DUM } \\
\hline & Beta & t- value & Beta & z- value \\
\hline Intercept & 3.8815 & $8.372^{* * *}$ & -27.2072 & $-8.712^{* * *}$ \\
\hline LEV & 6.4278 & $3.304^{* * *}$ & 4.0417 & $3.801^{* * *}$ \\
\hline INTCOV & -0.0279 & $-1.656^{*}$ & -0.0146 & -1.294 \\
\hline DEBTISS & -1.1668 & -1.166 & -0.6729 & -1.121 \\
\hline STOCKISS & -8.5680 & -0.941 & -4.3969 & -0.917 \\
\hline RISK & -0.6602 & $-4.096^{* * *}$ & -0.3874 & $-4.421^{* * *}$ \\
\hline FUND & -0.3324 & -0.136 & 0.1237 & 0.090 \\
\hline CLTD & 15.3176 & $3.556^{* * *}$ & 8.9072 & $3.822^{* * *}$ \\
\hline ETR & 0.5500 & 0.754 & 0.4368 & 0.955 \\
\hline INTAN & 5.3103 & 1.358 & 3.2037 & 1.433 \\
\hline DIRIND & 3.7901 & $1.716^{*}$ & 2.0588 & 1.627 \\
\hline INDSH & -4.1043 & -1.326 & -2.4861 & -1.274 \\
\hline LnSIZE & 1.2869 & $5.764^{* * *}$ & 0.7442 & $7.107^{* * *}$ \\
\hline INDU PERC & 162.2874 & $4.621^{* * *}$ & 99.8379 & $5.817^{* * *}$ \\
\hline $\mathrm{Chi}^{2}$ & \multicolumn{2}{|c|}{$329.395^{* * *}$} & \multicolumn{2}{|c|}{$325.856^{* * *}$} \\
\hline Pseudo $\mathrm{R}^{2}$ & \multicolumn{2}{|c|}{0.375} & \multicolumn{2}{|c|}{0.462} \\
\hline $\mathrm{N}$ & \multicolumn{2}{|c|}{15,068} & \multicolumn{2}{|c|}{15,068} \\
\hline
\end{tabular}

Please refer to Table 3 for variable definitions.

However, those determinants for the use of SPCs change with the adoption of the IFRS, as presented in Table 8. In particular, whereas the coefficient of LEV before IFRS adoption is significantly positive, after the adoption of the IFRS, it is not.

That is consistent with our conjecture that sponsors can no longer discretionally manage their debt ratio because, after IFRS adoption, they must consolidate their SPCs' financial statements into their own financial statements. As a result, the adoption of the IFRS diminishes the financial reporting motivation for sponsoring SPCs. 
However, the significance of the coefficients for RISK and CLTD before and after IFRS adoption is not qualitatively different, indicating that, even after IFRS adoption, sponsors use SPCs to raise capital. For companies that want to raise funds at lower cost, an SPC is still a popular financing vehicle.

The results reported in Table 8 support hypothesis 2 by showing that the use of SPCs is not related to financial reporting motivation after adoption of the IFRS.

Table 8. Analysis Results of the periods before and after IFRS adoption

\begin{tabular}{|c|c|c|c|c|}
\hline \multirow{4}{*}{ Variables } & \multicolumn{2}{|c|}{ Dependent Variable=SPC_NUM } & \multicolumn{2}{|c|}{ Dependent Variable=SPC_DUM } \\
\hline & Pre_IFRS & Post_IFRS & Pre_IFRS & Post_IFRS \\
\hline & Beta & Beta & Beta & Beta \\
\hline & (t-value) & (t- value) & (z- value) & (z- value) \\
\hline \multirow[b]{2}{*}{ Intercept } & 2.4983 & 4.9633 & -24.9268 & -69.4284 \\
\hline & $(6.783)^{* * *}$ & $(4.744)^{* * *}$ & $(-7.423)^{* * *}$ & $(-3.888)^{* * *}$ \\
\hline \multirow{2}{*}{ LEV } & 4.6892 & 5.9238 & 4.4467 & 3.2342 \\
\hline & $(3.174)^{* * *}$ & $(0.667)$ & $(3.577)^{* * *}$ & $(0.848)$ \\
\hline \multirow{2}{*}{ INTCOV } & -0.0146 & -0.1186 & -0.0117 & -0.0457 \\
\hline & $(-1.092)$ & $(-1.543)$ & $(-0.876)$ & $(-1.303)$ \\
\hline \multirow{2}{*}{ DEBTISS } & -0.8508 & -1.4418 & -0.7348 & -0.2996 \\
\hline & $(-1.167)$ & $(-0.350)$ & $(-1.050)$ & $(-0.174)$ \\
\hline \multirow[b]{2}{*}{ STOCKISS } & -4.9257 & -120.3938 & -3.6790 & -57.5365 \\
\hline & $(-0.962)$ & $(-1.632)$ & $(-0.947)$ & $(-2.160)^{* *}$ \\
\hline \multirow[b]{2}{*}{ RISK } & -0.3953 & -1.3435 & -0.3498 & -0.6476 \\
\hline & $(-3.284)^{* * *}$ & $(-2.374)^{* *}$ & $(-3.388)^{* * *}$ & $(-2.764)^{* * *}$ \\
\hline \multirow{2}{*}{ FUND } & -0.1574 & -15.5122 & 0.4603 & -8.7094 \\
\hline & $(-0.097)$ & $(-1.054)$ & $(0.297)$ & $(-1.479)$ \\
\hline \multirow{2}{*}{ CLTD } & 9.5763 & 55.1868 & 8.6311 & 22.9205 \\
\hline & $(2.937)^{* * *}$ & $(2.643)^{* * *}$ & $(3.107)^{* * *}$ & $(2.797)^{* * *}$ \\
\hline \multirow{2}{*}{ ETR } & 1.1422 & -2.9555 & 1.1205 & -1.3064 \\
\hline & $(1.847)^{*}$ & $(-1.500)$ & $(2.024)^{* *}$ & $(-1.614)$ \\
\hline \multirow[b]{2}{*}{ INTAN } & 1.4557 & 22.4747 & 1.8554 & 9.2227 \\
\hline & $(0.438)$ & $(1.900)^{*}$ & $(0.624)$ & $(1.903)^{*}$ \\
\hline \multirow{2}{*}{ DIRIND } & 3.2769 & -0.1038 & 2.7513 & -0.3642 \\
\hline & $(2.037)^{* *}$ & $(-0.013)$ & $(1.959)^{*}$ & $(-0.102)$ \\
\hline \multirow{2}{*}{ INDSH } & -2.1210 & -22.0149 & -1.7954 & -9.3744 \\
\hline & $(-1.025)$ & $(-1.087)$ & $(-0.879)$ & $(-1.076)$ \\
\hline \multirow{2}{*}{ LnSIZE } & 0.6974 & 5.5224 & 0.6423 & 2.0949 \\
\hline & $(4.570)^{* * *}$ & $(3.178)^{* * *}$ & $(5.759)^{* * *}$ & $(3.657)^{* * *}$ \\
\hline \multirow{2}{*}{ INDU_PERC } & 105.5369 & 242.5208 & 95.2336 & 130.8278 \\
\hline & $(3.929)^{* * *}$ & $(1.980)^{* *}$ & $(4.632)^{* * *}$ & $(2.646)^{* * *}$ \\
\hline $\mathrm{Chi}^{2}$ & $202.771^{* * *}$ & $153.145^{* * *}$ & $194.812^{* * *}$ & $155.519^{* * *}$ \\
\hline Pseudo $\mathrm{R}^{2}$ & 0.354 & 0.526 & 0.404 & 0.704 \\
\hline $\mathrm{N}$ & 9,207 & 5,861 & 9,207 & 5,861 \\
\hline
\end{tabular}

Please refer to Table 3 for variable definitions.

\section{CONCLUSIONS}

We examine which factors motivate sponsoring companies to use SPCs and whether those motivations differ before and after IFRS adoption. We use firm-year observations listed on KSE or KOSDAQ from 2004 to 2014. Our results, similar to those of prior research, show that the use of SPCs is motivated by financial reporting and economic considerations.

However, after adoption of the IFRS, the coefficient of leverage stops being significant, whereas the coefficients of firm risk, supply of internal funds, and repayable debt do not differ qualitatively before and after IFRS adoption. 
These results indicate that the financial reporting motivations for the use of SPCs disappear with IFRS adoption, while economic motivations continue to exist. In sum, since the adoption of the IFRS, companies use SPCs for economic reasons rather than financial reporting reasons.

We extend prior research by investigating whether the determinants for creating SPCs change due to adoption of the IFRS using a sample of Korean listed companies. We compare the motivation for SPC use under different accounting regulations. Our results show that financial reporting motivations disappear after IFRS adoption, which means that the IFRS regulations significantly affect the motivations to use SPCs.

This paper contributes to the literature by documenting the determinants of the use of SPCs and the consequences of IFRS adoption as the accounting environment by reporting the effect of the IFRS adoption on those determinants. Our findings suggest that the IFRS plays a crucial role in undermining the motivation to improperly use SPCs. Our examination of the role of IFRS regulation differs from previous studies by also analyzing SPC use in the non-IFRS environment.

We use a sample of Korean listed companies with SPCs under the ABS Act. However, it remains to be shown how companies create SPCs differently under other legal regimes. We leave this for future research.

\section{AUTHOR BIOGRAPHIES}

Su-In Kim, Ph.D., Researcher of Ewha School of Business Management Center, Ewha Womans University, Seoul, Korea. E-mail: amurtat2@hotmail.com (First Author)

Heejeong Shin, Ph.D., School of Business, Ewha Womans University, Seoul, Korea. E-mail: zimerman79@naver.com (Co-Author)

Hyejeong Shin, Ph.D., School of Business, Ewha Womans University, Seoul, Korea. E-mail: lasshin@hotmail.com (Corresponding Author)

\section{REFERENCES}

Barth, M. E., Ormazabal, G., \& Taylor, D. J. (2011). Asset securitizations and credit risk. The Accounting Review, 87(2), 423448.

Beatty, A., Berger, P. G., \& Magliolo, J. (1995). Motives for forming research \& development financing organizations. Journal of Accounting and Economics, 19(2), 411-442.

Berardino, J. (2001). Enron: A wake-up call. Wall Street Journal, 4, B17.

Brickley, J. A., Coles, J. L., \& Terry, R. L. (1994). Outside directors and the adoption of poison pills. Journal of financial Economics, 35(3), 371-390.

Byrd, J. W., \& Hickman, K. A. (1992). Do outside directors monitor managers?: Evidence from tender offer bids. Journal of Financial Economics, 32(2), 195-221.

Calomiris, C. W., \& Mason, J. R. (2004). Credit card securitization and regulatory arbitrage. Journal of Financial Services Research, 26(1), 5-27.

Dechow, P. M., Myers, L. A., \& Shakespeare, C. (2010). Fair value accounting and gains from asset securitizations: A convenient earnings management tool with compensation side-benefits. Journal of Accounting and Economics, 49(1), 2-25.

Dechow, P. M., Sloan, R. G., \& Sweeney, A. P. (1996). Causes and consequences of earnings manipulation: An analysis of firms subject to enforcement actions by the SEC. Contemporary Accounting Research, 13(1), 1-36.

Dichev, I. D., \& Skinner, D. J. (2002). Large-sample evidence on the debt covenant hypothesis. Journal of Accounting Research, 40(4), 1091-1123.

Dischinger, M., \& Riedel, N. (2011). Corporate taxes and the location of intangible assets within multinational firms. Journal of Public Economics, 95(7), 691-707.

Duke, J. C., \& Hunt, H. G. (1990). An empirical examination of debt covenant restrictions and accounting-related debt proxies. Journal of Accounting and Economics, 12(1-3), 45-63.

Feng, M., Gramlich, J. D., \& Gupta, S. (2009). Special purpose vehicles: Empirical evidence on determinants and earnings management. The Accounting Review, 84(6), 1833-1876. 
Fox, W. F., \& Luna, L. (2005). Do limited liability companies explain declining state corporate tax revenues?. Public Finance Review, 33(6), 690-720.

Gorton, G. B., \& Souleles, N. S. (2007). Special purpose vehicles and securitization. In The risks of financial institutions (pp. 549-602). University of Chicago Press.

Greene, W. H. (2003). Econometric analysis. Pearson Education India.Higgins, E. J., \& Mason, J. R. (2004). What is the value of recourse to asset-backed securities? A clinical study of credit card banks. Journal of Banking \& Finance, 28(4), 875899.

Hodge, J. B. (1998). The synthetic lease: Off-balance-sheet financing of the acquisition of real property. Real Estate Finance Journal, 14(2), 59-76.

John, T. A., \& John, K. (1991). Optimality of project financing: Theory and empirical implications in finance and accounting. Review of Quantitative Finance and Accounting, 1(1), 51-74.

Karaoglu, E. (2005). Regulatory capital and earnings management in banks: The case of loan sales and securitizations.

Klein, A. (1998). Firm performance and board committee structure 1. The Journal of Law and Economics, 41(1), $275-304$.

Korean Financial Supervisory Service. (2012). ABS practical guidance.

Larcker, D. F., Richardson, S. A., \& Tuna, I. (2007). Corporate governance, accounting outcomes, and organizational performance. The Accounting Review, 82(4), 963-1008.

Lockwood, L. J., Rutherford, R. C., \& Herrera, M. J. (1996). Wealth effects of asset securitization. Journal of Banking \& Finance, 20(1), 151-164.

Mills, L. F., \& Newberry, K. J. (2005). Firms' Off-Balance Sheet and Hybrid Debt Financing: Evidence from Their Book-Tax Reporting Differences. Journal of Accounting Research, 43(2), 251-282.

Powers, W.C. (2002). Report of investigation by the special investigative committee of the board of directors of Enron Corp.

Press, E. G., \& Weintrop, J. B. (1990). Accounting-based constraints in public and private debt agreements: Their association with leverage and impact on accounting choice. Journal of Accounting and Economics, 12(1), 65-95.

Rosenthal, J. A., \& Ocampo, J. M. (1988). Analyzing the economic benefits of securitized credit. Journal of Applied Corporate Finance, 1(3), 32-44.

Schwarcz, S. L. (1994). The Alchemy of asset securitization. Stanford Journal of Law, Business, and Finance, 1, 133.

Shevlin, T. (1987). Taxes and off-balance-sheet financing: research and development limited partnerships. Accounting Review, 62(3), 480-509.

Soroosh, J., \& Ciesielski, J. T. (2004). Accounting for special purpose entities revised: FASB Interpretation 46 (R). The CPA journal, 74(7), 30 .

Teoh, S. H., Welch, I., \& Wong, T. J. (1998). Earnings management and the underperformance of seasoned equity offerings. Journal of Financial Economics, 50(1), 63-99.

Thomas, H. (1999). A preliminary look at gains from asset securitization. Journal of International Financial Markets, Institutions and Money, 9(3), 321-333.

Weidner, D. J. (1999). Synthetic leases: Structured finance, financial accounting and tax ownership. J. Corp. L., $25,445$.

Wooldridge, J. M. (2010). Econometric analysis of cross section and panel data. MIT press. 